\title{
The Impacts of Oil Prices, Exchange Rate and COVID-19 Pandemic on BIST Petrochemical Market
}

\author{
Seval Mutlu ÇamoĞLua \\ Received: 15.04.2021; Revised: 19.05.2021; Accepted: 21.05.2021
}

\begin{abstract}
Stock markets are developing with the economic growth of the countries in a liberal market economy. Petrochemicals is an indicator of the performance of the country's industry with high inter-industry linkage by providing input to several sectors, producing various outputs with a certain number of raw materials. The COVID-19 pandemic period has affected all markets worldwide and caused fluctuations in the index values of large firms in the petrochemical industry in Borsa Istanbul (BIST). This study analyzes the impact of the pandemic period and change in the oil prices and exchange rate on the petrochemical market in Turkey. The monthly data of petrochemical stock market index, exchange rate, oil prices are used in this time series analysis. A pandemic information index representing the COVID-19 pandemic was derived and included in the model. According to the results, it is observed that the most important determinant of the fluctuations on the BIST petrochemical index is the oil prices. While a shock in oil prices negatively affects the BIST petrochemical index, the petrochemical index responds positively to the shock in the pandemic index.
\end{abstract}

JEL codes: N50, G10, E4

Keywords: Petrochemical stock market, Pandemic information index, Oil prices, Time series analysis

\section{Introduction}

The stock market grows together with the economic developments in free-market economies. This financial market drives savings and allocates capital to the economy. The increasing number of institutional and individual financial investors increases the role of this market. Levine \& Zervos $(1996,323)$ emphasized that there is a positive and strong relationship between long-term economic growth and the development of stock markets. Financial markets (stock markets and banks) are the prominent way to channel investment capital into uses of the highest returns. These markets foster entrepreneurship development and specialization in the adoption of new technologies with enhanced capital accumulation (Greenwood \& Smith, 1997, 147). As the stock market grows and becomes more institutional, the possibility of savings to turn into investments increases and economies develop more steadily.

a Department of Economics. Ünye Faculty of Economics and Administrative Sciences, Ordu University/Turkey. email: smutlu28@gmail.com (D) https://orcid.org/0000-0003-3056-7895 
In recent years, small savers have become more interested in the stock market, which can have attractive returns, as they are directed to savings through financial instruments such as interest, gold, foreign exchange. Especially after March 2020, more than two million new investors entered the stock market (Korcan, 2021). The simplicity of online banking transactions and the increase in the time spent at home during the COVID-19 pandemic, as well as more spare time for market monitoring, have led individuals with savings to different pursuits in terms of financial returns.

Petrochemical firms in the stock market, which are large-scale firms, are producing chemical, petroleum and plastic materials, could be relatively stable compared to the other stock markets. The petrochemical index is affected by several local and international information. In addition to the fluctuations in oil prices and exchange rates, the COVID-19 pandemic has also considerably influenced the sector. Social distancing measures during the pandemic caused demand shocks by reducing consumption expenditures, resulting in chain reaction supply shocks and serious ups and downs in the financial markets.

The fluctuations in oil prices could considerably affect the economic indicators. This is due to the fact that oil is an intermediate input for many sectors. Oil price shocks are spreading rapidly due to internationally integrated markets, reflecting particularly on production costs, creating inflationary effects in oil-importing and highly dependent countries. Özer (2017) and Gönüllü et al. (2015) stated that oil prices are an effective determinant, although not the most important, for stock markets.

The pandemic has negatively affected economies, causing sudden declines in stock markets. Most countries have turned to both fiscal and monetary expansion by implementing more Keynesian policies in the pandemic. During this period, the scope of government responsibilities in market economies expanded, and more social policies were implemented (Çolak, 2020, 3). The COVID-19 pandemic, which started in Turkey in March 2020 and is still having an impact, has affected the economy completely, driving the implementation of measures such as travel restrictions, distance education instead of face-to-face education, and the closure of shopping malls. Commercial life has changed dramatically, and electronic commerce has become more widespread. Food and drinking establishments have become unworkable by minimizing social life, while sectors that provide food, health and hygiene products have become more profitable.

Decreases in household expenditures due to social distance measures taken to prevent the spread of COVID-19 have caused demand shocks. The demand shocks affected production, resulting in supply shocks in both final products and intermediate goods. All these also trigger financial shocks (Aydoğuş, 2020, 11). The sharp ups and downs in the stock market have caused particularly inexperienced individuals who have just entered the market to live with high-rate losses (Gürdamar, 2020). The aim of this study is to analyze the interaction of oil prices and exchange rates, which are the determining variables of the petrochemical market, as well as the COVID-19 pandemic on the BIST petrochemical stock market.

In this paper, the monthly data for the chemical, petroleum and plastic stock market index of BIST, the exchange rate of US dollar (USD)/Turkish Lira (TRY), the oil prices and the information index of COVID-19 for Turkey were analyzed within the framework of the VAR (Vector Autoregressive) model. The information index of the COVID-19 pandemic was generated based on the method of the information index developed by Chern \& Zuo (2006) as representing the pandemic period for the analysis in the model of this study. 
In the next section, a literature review is provided. Section 3 discusses the characteristics of the petrochemical industry. Section 4 describes the data used in the model and sets out a framework for the empirical approach. Section 5 presents the results of the empirical analysis by providing impulse response function and variance decomposition. Section 6 concludes. The appendix provides additional tables regarding the results of the variance decomposition analysis, lag length selection, and block exogeneity test.

\section{Literature Review}

There are many studies that examine different sides of the linkages among oil prices, stock markets and exchange rate. In particular, the effects of the volatility in oil prices on the markets have been of extra interest.

Mensi (2019) examined the joint movements between crude oil prices and stock market indices at the sector level in the Saudi market, which is a heavily oil-dependent economy. The author used the Value at Risk (VaR) and wavelet approach for analysis. The co-movements among oil prices and the aggregate index (Tadawul) and all sector markets intensified after the 2008-2009 global financial crisis. The joint movements between Brent crude oil and the Tadawul were weak due to government spending, high foreign reserves and economic indicators. The Petrochemical sector index was highly dependent on the oil market.

Gourène \& Mendy (2018) examined the co-movements between OPEC oil prices and Africa's six largest stock markets. Using the Wavelet approach, they found that with the exception of emerging stock markets such as South Africa and Egypt, the joint movement between African stock markets and oil prices was relatively low.

Liu et al. (2020) studied the impacts of oil price jumps on China's petrochemical markets. They found evidence that the threat of dynamic shock in oil prices still exists in the post-2008 crisis period. The returns of petrochemical stocks and commodities were negatively affected by current oil price jumps because of early reflections of the panic caused by excessive risk information. The effects of lagged jumps on these returns were the opposite due to the reflection of rationality in speculators.

Öztürk et al. (2013) investigated the relationship between oil and natural gas prices, the petrochemical industry index and the manufacturing sector index in the Turkish stock market for the period of 1997-2009. According to the results of the tests with structural breaks, they found a long-term relationship between the variables.

Gönüllü et al. (2015) conducted regression analyses for the 2003-2012 periods in order to reveal the return effect of the volatility in oil prices on stock prices. They stated that, in cases where there is a positive change in oil prices and the Turkish stock market index, positive returns could also be achieved in the petrochemical industry. Caporale et al. (2015) estimated the time-varying effect of oil price uncertainty on sectoral stock returns in China using the VAR-GARCH model. They found that the increase in oil prices positively affected stock returns during periods of demand-side shocks and that financial, oil and gas stock returns reacted negatively to oil price uncertainty during periods of supply-side shocks.

Atarodi et al. (2018) examined the effects of exchange rate fluctuations and oil prices on Iran's petrochemical industry stock market prices. They took into account the stock market index of firms in the petrochemical industry using the vector error correction model in the period 1992-2015. The results show that exchange rate fluctuations and oil prices have a positive relationship with the stock market prices of the Iranian petrochemical industry. 


\section{Petrochemical Industry}

Petrochemicals is an industry that produces materials used in many parts of modern daily life. The growth of the plastics and rubber sectors has been effective in its main development. The widespread use of plastic and rubber in automobile and all other sectors has significantly increased petrochemical production. The size of the global petrochemical market was around $\$ 700$ billion in 2018 (PAGEV, 2021). Petrochemicals is an industry that provides many outputs with a certain number of raw materials, has high inter-industry forward connections and is indicative of the performance of the country's industry by providing input to many sectors (Oğuz, 2018, 81).

During the $20^{\text {th }}$ century, the petrochemical industry was dominated by a certain number of European and U.S. based multinational firms with strong barriers to entry into the market. By the 2000s, China became the world's largest producer in the sector, and emerging economies have also increased their production recently. The petrochemical industry underperformed for a short while in 2015. This could be attributed to changes in oil prices, weak global demand, and a decline in Chinese imports (Verbeek \& Mah, 2020, 364). Excessive volatility in oil prices has a dramatic effect on petrochemical stocks and commodity markets of importing countries in particular due to the fact that petrochemicals are direct by-products of crude oil (Liu et al., 2020, 2). Petroleum is the main raw material of the petrochemical industry.

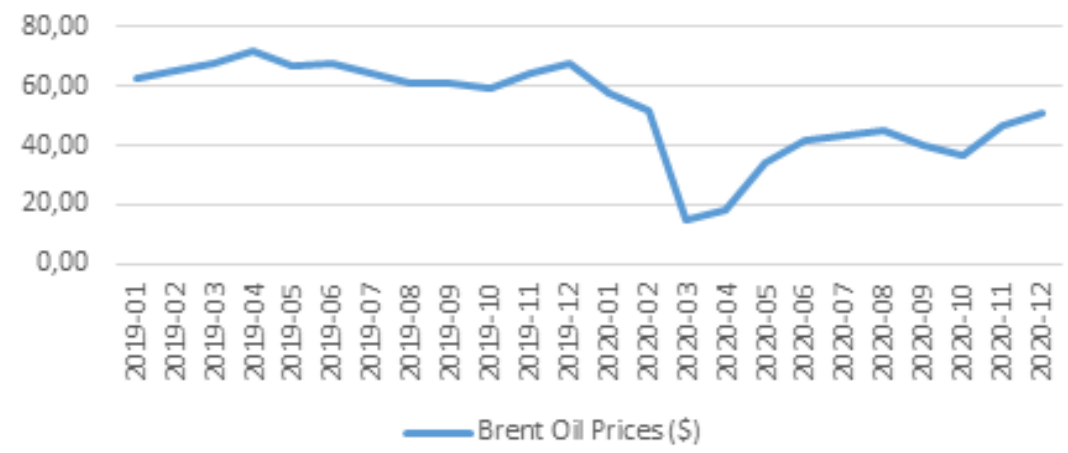

Figure 1: Brent Oil Price

Source: CBRT (2021)

Many products derived from petroleum are used in sectors such as construction, packaging, automotive, electrical electronics and fertilizers. Therefore, oil is an effective commodity in the development of these industries. The international oil market has a complex structure that is under the influence of many factors. The activities in the market carried out with factors such as the interdependent political decisions of the countries, production costs, technological developments and fluctuations in the spot and futures markets (Bayraç, 2019, 45). During the COVID-19 outbreak, restriction measures in the mobility of individuals significantly reduced expenditures, outcoming a demand shock in the markets, and the industrial sector caused reductions in energy demand, fuel consumption and production of the petrochemical industry. This has led to a sudden drop in oil prices, especially in the first months of the pandemic. Brent oil price decreased from \$50/barrel in February 2020 to $\$ 15 /$ barrel in March 2020 (Figure 1). The increasing fluctuations in commodity prices during the pandemic brought speculative movements and severe instability to financial markets. 


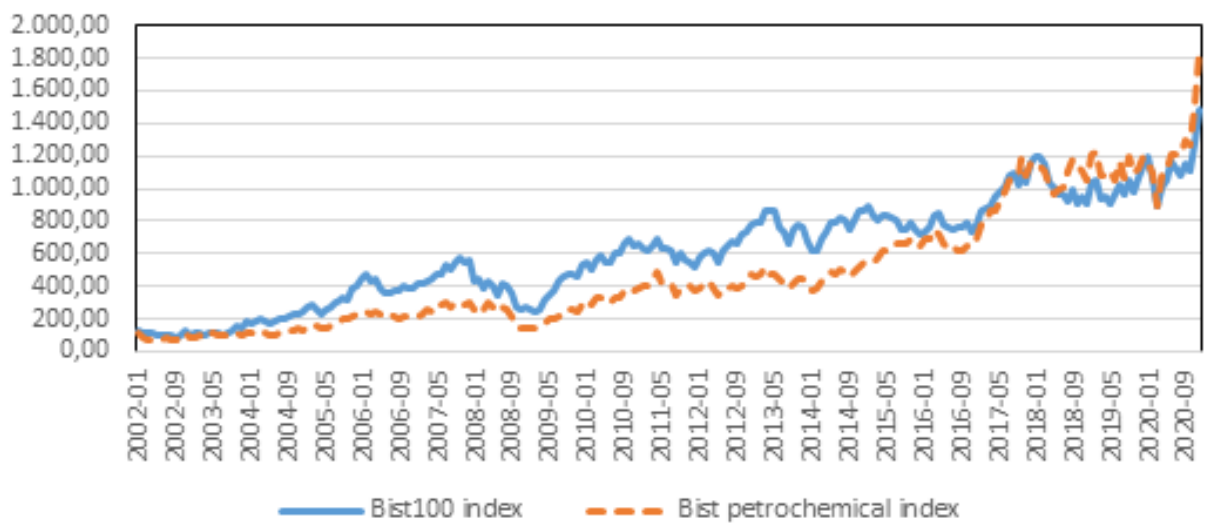

Figure 2: BIST Petrochemical Index and BIST100 Index Source: (Investing, 2021)

In this study, the index value of BIST oil, chemistry and plastics (XKMYA) representing the petrochemical industry was taken into consideration. This index group includes the stocks of 31 firms in Borsa Istanbul. In this sector, a wide range of products such as cellulose, chemical products, fertilizers, insulation materials, packaging, polyester, petroleum refinery products and so on are produced.

When the aggregate index (BIST100) and the petrochemical index are examined in Figure 2, it is seen that the index of this sector is below the BIST100 until 2018. However, many times after 2018, the stock prices of this sector have risen above BIST100. When the real monthly return of the sector index is evaluated, it is seen that between 2000-2003, during the 2008 financial crisis, and since 2019, volatilities in real return values have been quite high. The return of this sector in the stock market was affected by the shocks in the crisis years, and fluctuations were experienced. The lowest level was recorded with a

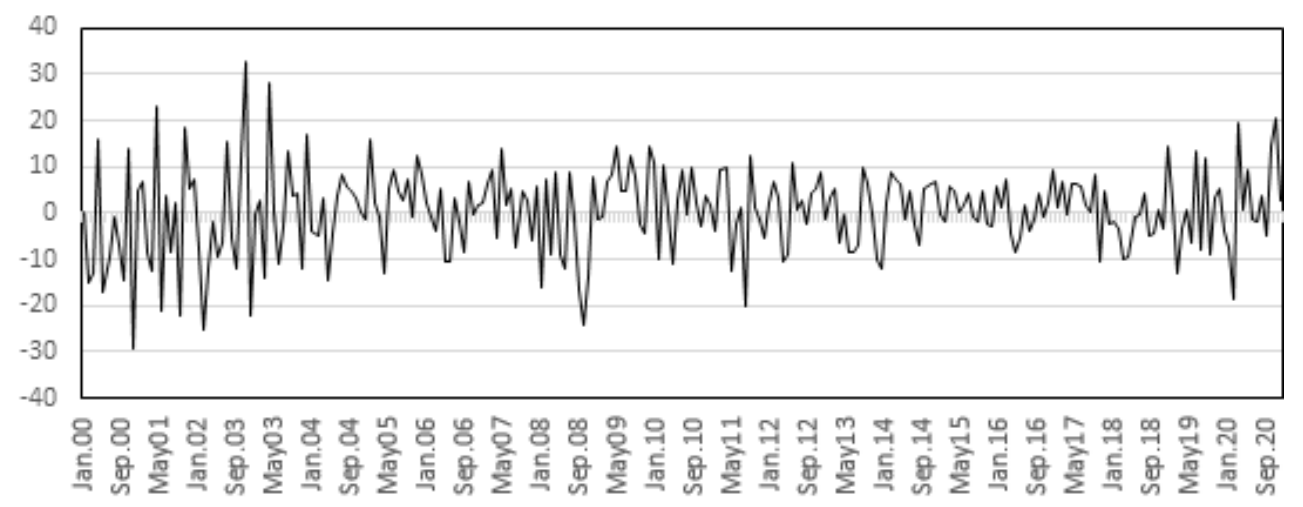

Figure 3: Real Returns on the BIST petrochemistry Index (\%) Source: Returns are calculated by the author using data from Investing (2021)

real return loss of $30 \%$ in November 2000 and the highest level with a real return of about $33 \%$ in November 2002. COVID-19 pandemic in Turkey started in March 2020, and the sector shares suffered a sudden devaluation of approximately $19 \%$, Figure 3 . The pandemic 
has affected oil prices much more deeply. Oil prices, which were already in a downward trend since the beginning of 2020, fell at a high rate of $71 \%$ in March 2020 compared to the previous month, Figure 1.

\section{Data and Method}

In this research, the time series monthly data for the BIST petrochemical stock market index, the dollar exchange rate and oil prices are used for analysis. In addition, after March 2020, the Pandemic index was created and included in the model to analyze the effects of the COVID-19 pandemic in this market. As the exchange rate variable, the average monthly data of the purchase value of a U.S. dollar for the Turkish lira is used. Oil prices are the average monthly price of European Brent oil in dollars per barrel. These are taken from the Central Bank of the Republic of Turkey database (CBRT, 2021). BIST petrochemical index was converted to real data by using the domestic producer prices index (TURKSTAT, 2021). This stock market index is the monthly average value of closing stock data and is taken from the investing.com website (Investing, 2021). The data required for the Pandemic index, which was generated to evaluate the effects of the COVID-19 pandemic on the markets, was obtained from the website of the Ministry of Health of the Republic of Turkey (MoH, 2021).

In this study, the pandemic index variable is generated based on the method developed by $\mathrm{MoH}$ (2021) by using the total number of persons who died due to COVID-19 announced by the Ministry of Health on a monthly basis in Turkey. Economic decision-making units are expected to suddenly adjust and change their behaviors when faced with a life-threatening situation. Time series data is quite appropriate for capturing such changes. Brown \& Schrader (1990) contributed to the literature by generating an information index based on the number of piece of news published on the subject to show the level of information dissemination impact of an event. Following their approach, there have been attempts to construct alternative indices. These studies assume that the level of influence of information decreases over time after a piece of news is published (Chern \& Rickertsen, 2003). The information index $\left(I_{i}\right)$ developed by Chern \& Zuo (2006) is defined as follows.

$$
I_{i}=\sum_{i=0}^{n} W_{i} N_{t-i}
$$

where $N_{t-i}$ is the number of information related to the event in the $(t-i)^{t h}$ period, $n$ is the number of total lagged periods, and $W_{i}$ indicates the cubic weight function associated with $i$ during the derived lagged period, equation (1). This method considers not only the carryover effect but also the decay effect of information. The carryover and decay effects are captured by specifying a weight function and the total lag period. The following third-degree or polynomial weight function is used.

$$
\begin{gathered}
W_{i}=\frac{2 a}{(n+1) b}+\frac{12 m}{b} i-\frac{6(n+1+m)}{(n+1) b} i^{2}+\frac{4}{(n+1) b} i^{3} \\
a=(n+1)^{2}(n+1-3 m) \\
b=(n+2)[(n+1) 2-m(2 n+3)]
\end{gathered}
$$

where $m$ is the lag period with the maximum weight, $a$ and $b$ are calculated from $m$ and $n$, equation (2). In general, $m$ and $n$ can take any finite numbers. The trends of the information 
index are not very sensitive to the values of $m$ and $n$. The validity of these indexes lies in the assumption that the receiving information should have a finite duration and decaying effects as a source of consumer information (Chern \& Zuo, 2006, 9-12).

In this study, the vector autoregressive (VAR) model was applied according to the findings of unit root tests and cointegration tests to reveal the effects of the variables specified in the petrochemical market. VAR processes reveal the dynamic interactions of $\mathrm{n}$ numbers of time series variables, where a priori endogeneity is assumed for each variable (Chern \& Zuo, 2006, 95). In its configuration, the current values of the set of variables are formed to be partially explained by the lagged values of the variables. This model was developed by Sims (1980). The basic VAR model could be described in the following reduced form, equation (2), based on Lütkepohl \& Kratzig (2004).

$$
y_{t}=A_{1} y_{t-1}+\ldots+A_{p} y_{t-p}+\epsilon_{t}
$$

where $y_{t}$ is a $(n x 1)$ vector containing the model variable, $A_{i}$ is the parameter matrix containing coefficients, and $\epsilon_{t}$ represents the unobserved error terms that are a vector with Gauss distribution (Kiss et al. (2020, 95); Johansen (1995)). Traditional VAR models are generated with stationary variables (Lütkepohl, 2015, 2). Augmented Dickey-Fuller (ADF) and Phillips Perron (PP) unit root tests were applied to test the stationarity of the data. The null hypothesis of the ADF and PP tests is "with unit root and not stationary" (Dickey \& Fuller, 1979; Phillips \& Perron, 1988). Johansen Cointegration analysis was conducted to determine the existence of cointegration between non-stationary series. In order to capture stochastic trends in economic variables, the concept of cointegration was developed by Engle \& Granger (1987), Johansen (1995) and others (Lütkepohl, 2015, 2)). Next, Block Exogeneity Wald tests were adopted to support the inclusion of endogenous variables for the set of variables in the VAR system. The Wald statistic is useful in detecting exogeneity or endogeneity of the dependent variable (Rafiq et al., 2009). Under this test, an endogenous variable can be treated as exogenous (Constant, 2010). Wald chi-square test was found to be statistically significant jointly in equations where the dependent variables were exchange rate and oil prices. The null hypothesis of block exogeneity is rejected for the exchange rate and oil prices equations in the model. Besides, the variable of oil prices is statistically significant in the equation, where the dependent variable is the pandemic index. Also, the petrochemical stock market index and the pandemic index are statistically significant, while the dependent variable is oil prices. There was evidence of bi-directional causality between the pandemic index and oil price, which implies that they are influenced by each other. In the equation where the exchange rate is dependent, the petrochemical stock market index was found to be significant. According to Wald test results, these variables can be treated as endogenous variables in the model (Table A.3 in Appendix).

In this study, impulse-response functions and variance decomposition were used as tools to explain the relationships between the variables in a VAR model. The effect of a unit shock applied to each variable is measured by the impulse-response functions in order to determine the response of the variables used in the model to the specific variable. In the impulse-response graph, the vertical axis measures the magnitude of the response to the effect by scaling so that 1.0 equals one standard deviation. Confidence bands used to determine the statistical significance of an impulse-response represent \pm 2 standard errors. At points where the confidence bands do not exceed the line at zero, the impulse response is 
considered to be statistically different from zero at a significance level of $5 \%$ or less (Ewing et al., 2007, 609-610). The variance decomposition method is used to determine which variables are caused by the percentage change in the specific variable (Ataş \& Güler, 2020, 528-529). Variance decomposition indicates which shocks are determinant in the short and long term paths of certain variables, that is, the proportion of uncertainty of the $i^{\text {th }}$ variable to be attributed to the $j^{t h}$ shock after the h period Kiss et al. $(2020,97)$. The variance decomposition is formulated as follows.

$$
\vartheta D_{i, j, h}=\frac{\sum_{k=0}^{h}\left(k c_{i, j}\right)^{2}}{\sum_{k=0}^{h} \sum_{l=1}^{n}\left(k c_{i, l}\right)^{2}}
$$

\section{Empirical Findings}

First, the natural logarithmic transformation of each time series data was performed. Descriptive statistics for this data are presented in Table 1. The trends of the data used in the model between 2000-2021 are presented in Figure 4. When the nominal data of the BIST petrochemical index are examined, it is seen that the stock market has tended to increase in this sector, particularly after the 2008 Global Financial Crisis. The real BIST petrochemical index was found to be a more stable series. In the graph of oil prices, it is seen that oil prices are affected especially by crisis periods and followed a fluctuating. Turkey's pandemic index has been increasing since March 2020, with a slight decrease in the summer period but a significant increase in the last quarter of the year. The TL/dollar exchange rate was stable in the early 2000s, but after 2016, an increasing trend is observed.

Table 1: Descriptive Statistics

\begin{tabular}{|lcccc|}
\hline & LogPbrentoil & Logpandemicindex & Logreelbistpetrochemical & Logusdtrrate \\
\hline Mean & 1.786 & 0.147 & 2.270 & 0.329 \\
Median & 1.803 & 0.000 & 2.294 & 0.232 \\
Maximum & 2.141 & 3.715 & 2.587 & 0.903 \\
Minimum & 1.172 & 0.000 & 1.918 & 0.068 \\
\hline Observations & 229 & 229 & 229 & 229 \\
\hline
\end{tabular}

Source: Calculated by the author by using data of CBRT (2021) and Investing (2021)

Constant and trend-containing ADF and PP tests were applied for unit root analysis of the series in the study. The results in both tests confirmed each other. Accordingly, it was determined that oil prices and dollar exchange rates were not stationary at the level. This suggests that the past shocks of each series continue to have an effect for a certain period. As a result of the unit root test performed for the differences, the series becomes stationary and are first-order stationary series, Table 2. The Johansen cointegration test was used to investigate whether the series were co-integrated, that is, whether the variables have a long-term equilibrium. As a result of the cointegration test, no long-term relationship was found between variables, Table 3 .

Since there is no co-integrated relationship, it is decided to apply the unconstrained VAR model and, thus, the relationship between the variables is examined with the simultaneous equation system. The difference series of oil prices and dollar exchange rates, which are the series whose first-degree difference is stationary, are created. The BIST petrochemical index is stationary at the level according to the result of unit root tests, Table 2. 


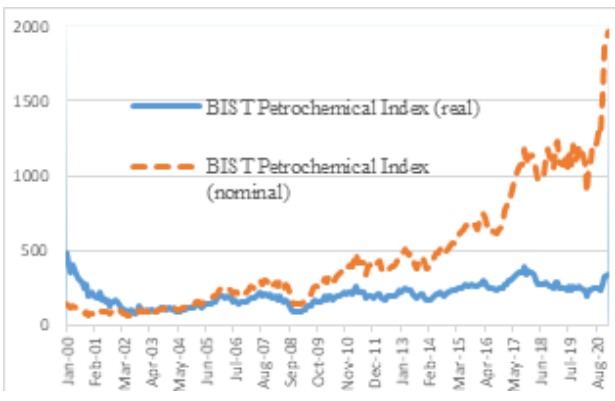

(a) BIST Petrochemical Index (Real and nominal)

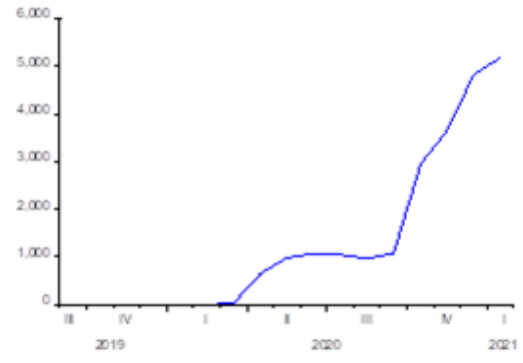

(c) COVID-19 Pandemic Index

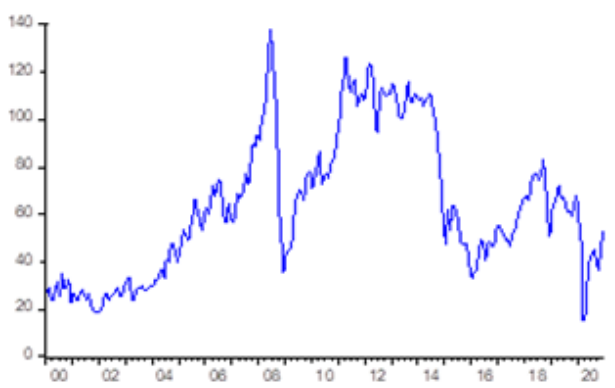

(b) Brent Oil Prices

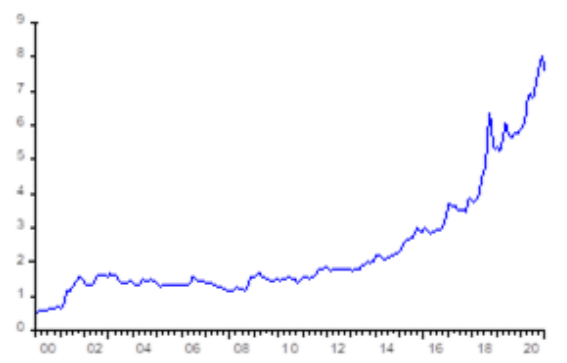

(d) Turkish Lira/Dollar Exchange Rate

Figure 4: The Evolution of Variables in Interest

Source: Calculated and graphed by the author by using data of CBRT (2021) and Investing (2021)

Based on the assumption that each variable is endogenous, the VAR model was formed to reveal the dynamic relationship of the variables in the study. In addition, the pandemic index variable has been added to the model as an endogenous variable. The lag length of the model is determined as three according to the AIC criterion (Table A.2 in Appendix). It is

Table 2: Unit Root Hypothesis Test Results

\begin{tabular}{|l|cc|cc|}
\hline \multirow{2}{*}{ Variables } & \multicolumn{2}{|c|}{ ADF test $^{a}$} & \multicolumn{2}{c|}{ PP test $^{a}$} \\
\cline { 2 - 5 } & Level & $1^{\text {st }}$ Difference & Level & $1^{\text {st }}$ Difference \\
\hline logreelbistpetrochemical & $-3.729^{* *}$ & $-15.596^{* * *}$ & $-4.090^{* * *}$ & $-15.610^{* * *}$ \\
logPbrentoil & -2.577 & $-10.007^{* * *}$ & -2.665 & $-13.676^{* * *}$ \\
logusdtrrate & -1.015 & $-8.148^{* * *}$ & -1.024 & $-9.768^{* * *}$ \\
\hline
\end{tabular}

$* \% 10, * * \% 5$, and $* * * \% 1$ are significance levels.

a: Lag length is selected based on Akaike Information Criterion. Tests include constant and trend.

important to accurately determine the optimum lag length in order to be consistent in the results of impulse-response function and variance decomposition analysis (Elmastaş Gültekin \& Aktürk Hayat, 2016, 618). LR autocorrelation test was performed to test whether the model had a problem with the error terms; it was determined that there was no autocorrelation in the model (Table 4). Impulse response functions and variance decomposition were used to interpret the model estimation results and resolve relationships among variables.

In order to determine the effect of the variables in the model on the BIST petrochemical index, firstly, the graphical analysis of the impulse response functions was carried out. Impulse response functions indicate the current and future values of each variable within 
Table 3: Johansen Cointegration Test

\begin{tabular}{|l|cc|cc|c|}
\hline \multirow{2}{*}{ Model } & \multicolumn{2}{|c|}{$\lambda \max$} & \multicolumn{2}{|c|}{$\lambda$ trace } & \multirow{2}{*}{ lag } \\
\cline { 2 - 5 } & $r=0$ & $r=1$ & $r=0$ & $r=1$ & 3 \\
\hline $\log$ Pbrentoil \& logusdtrrate & 7.279 & 1.128 & 8.408 & 1.128 & 3 \\
\hline
\end{tabular}

$* \% 10, * * \% 5$, and *** \%1 are significance levels.

Note: $\mathrm{r}$ is the number of cointegrated vectors, $\lambda$ max is Maximal eigenvalue test, and $\lambda$ trace is Trace test.

the VAR model in response to an increase in the system by one standard deviation. It is assumed that the effect of this shock disappears after a while (Stock \& Watson, 2001). These effects enter the system through the vector of error terms (Lütkepohl, 2015, 16). In the study, the VAR model was first estimated, and then Impulse-Response Functions

Table 4: LR Autocorrelation Test Results of the VAR model

\begin{tabular}{|l|ccc|ccc|}
\hline Lag & LRE* stat & df & Prob. & Rao F-stat & df & Prob. \\
\hline 1 & 20.692 & 16 & 0.191 & 1.300 & $(16,611.6)$ & 0.191 \\
2 & 13.216 & 16 & 0.657 & 0.825 & $(16,611.6)$ & 0.657 \\
3 & 16.302 & 16 & 0.432 & 1.021 & $(16,611.6)$ & 0.432 \\
4 & 20.474 & 16 & 0.199 & 1.286 & $(16,611.6)$ & 0.199 \\
5 & 20.366 & 16 & 0.204 & 1.279 & $(16,611.6)$ & 0.204 \\
\hline
\end{tabular}

Note: Sample covers 2002M01-2021M01, and the number of observations is 224 .

$\mathrm{H}_{0}$ : There is no autocorrelation.

graphs were orthogonalized according to Cholesky decomposition following the ordering petrochemical index, oil prices, exchange rate, and pandemic index (Figure 5). The impulse response function is statistically significant when both confidence bands are above or below zero on the y axis representing plus/minus two standard deviations (Weinhagen, 2002, 7). At points where the confidence bands do not straddle the line at zero, the impulse response is considered to be statistically different from zero at the $5 \%$ level of significance or less (Ewing et al., 2007, 609-610).

The impact of an increase in oil prices on the BIST petrochemical index is negative and has a growing trend, and this effect does not return to its former state in the long period. Fluctuations in the prices of oil, which is the main raw material of the petrochemical sector, change the input costs of this sector and affect the profitability of the sector. The shocks in oil prices have statistically significant reactions to the petrochemical index.

Shocks to the petrochemical index cause statistically significant changes in oil prices and exchange rates in the first periods. The increases in the exchange rates have a substantial impact on the production costs of the petrochemical industry, which has import-dependent input demand. Contractions in the production of industries also led to decreases in input demand, resulting in decreases in oil prices.

The pandemic index, as an indicator of the public concern for COVID-19, has a positive effect on the stock market petrochemical index, and there is a response to the increase in the stock prices of firms in this sector. This effect continues to increase in the following months. In the first period of the pandemic, the stock market observed a sharp decrease in the stock market, there was an upward trend in the following period, and the markets reached their pre-pandemic level. 

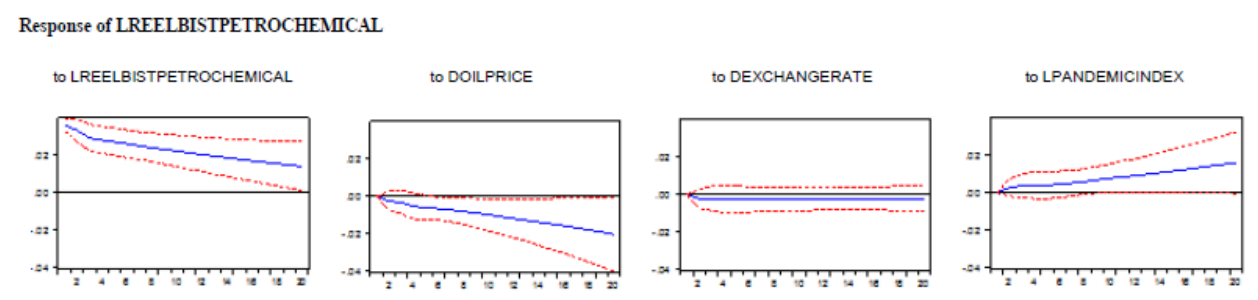

Response of DOILPRICE
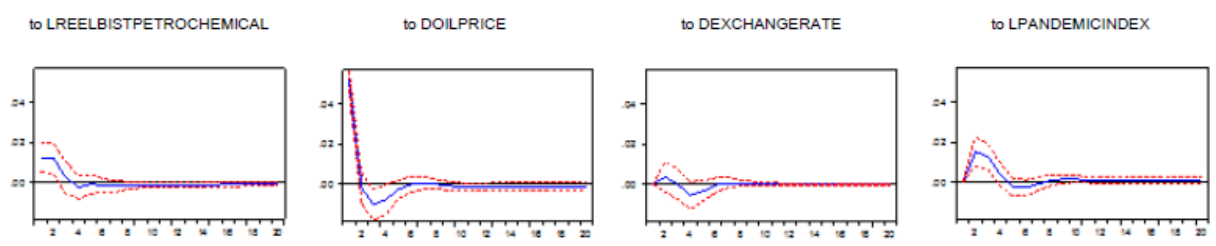

Response of DEXCHANGERATE
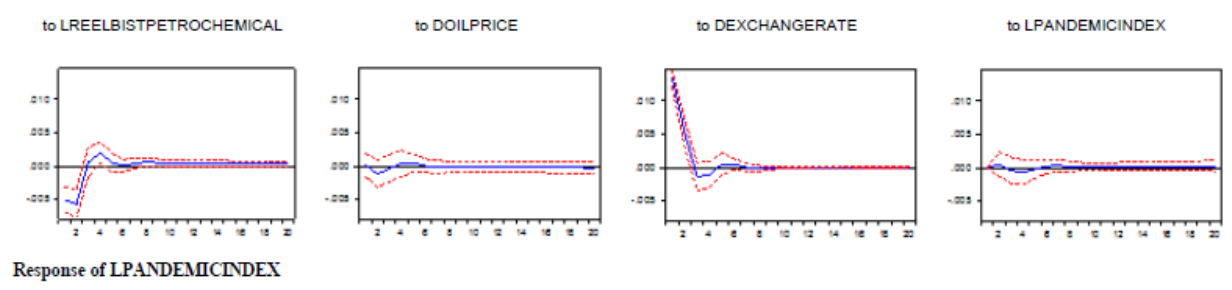

to LREELBISTPETROCHEMICAL
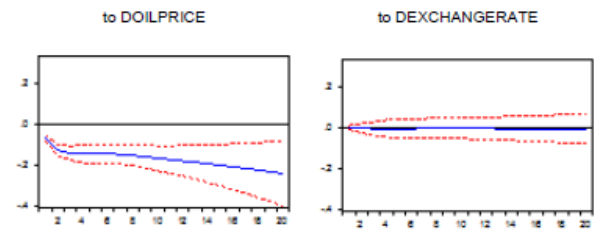

to LPANDEMICINDEX

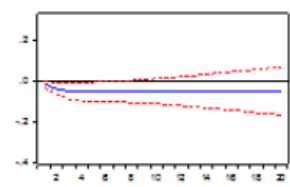

Figure 5: The Impulse Response Functions of the Model

Source: Calculated and graphed by the author by using data of CBRT (2021) and Investing (2021)

The BIST petrochemical index is examined according to variance decomposition in Table A.1 in Appendix. It is reported that it is most affected by its variability in its own innovations. The changes in oil prices to explain the variability in the petrochemical index remains very low in the first months, and the effect reaches $7 \%$ in a year. The changes in the dollar exchange rate to explain the fluctuations in the petrochemical index is quite weak and remains constant at $0.5-0.6 \%$ towards the end of the year. It is observed that approximately $4.2 \%$ of the variability in petrochemical index changes is explained by pandemic index shock at the end of the year, while the influence to explain the variability in the BIST petrochemical index was quite small in the first months of the year.

While oil prices are examined by variance decomposition, the pandemic index has the greatest effect on oil prices after its own changes. This effect continues at $11 \%$ for a year. The second influential variable in oil price variability is the stock market index of petrochemical firms, which continues to have this effect throughout the year at about $9 \%$. In the volatility in oil prices, the explanatory level of the dollar exchange rate increases throughout the year and reaches $2 \%$. 


\section{Conclusions}

This study aims to analyze the effects of the COVID-19 pandemic on the BIST petrochemical stock market, as well as the oil prices and exchange rate, which are the influential variables on the petrochemical market. The VAR model was used to reveal dynamic interactions between the BIST petrochemical index, oil prices, the dollar exchange rate and the pandemic index variables generated. Impulse response functions and variance decomposition were used to interpret model results and to explain the relationships between variables. According to the impulse-response graphs, the effect of the increase in oil prices on the BIST petrochemical index is negative. The increase in the dollar exchange rate also negatively affects the index of the sector. The pandemic index is an indicator of the public concern caused by the impact of the COVID-19 disease. This index had a positive effect on the stock market petrochemical index.

According to the results of variance decomposition, it is observed that oil prices are the most important factor in the variability of the BIST petrochemical index. The shock in oil prices negatively affects the BIST petrochemical index. The most important variable in the variability in oil prices was found to be the pandemic index. Afterwards, the stock market index is effective immediately after the exchange rate. The international impact of the COVID-19 pandemic has led to significant movement in international oil prices. In the statement of the movements in the dollar exchange rate, the value of the petrochemical index is seen as significantly important. These variables dynamically interact with each other. A crisis such as the pandemic has caused a decrease in the demand for consumer goods and affected oil prices, making the BIST petrochemical index more volatile.

Knowledge about the determinants of stock market volatility is crucial in assisting investors to choose the appropriate financial investment instruments to minimize risk, especially in times of uncertainty. As the number of investors increases in the developing stock markets, the regulations to be made for these markets are also important, especially during periods of increased risk factors. Crises that change people's daily lives and consumption behaviors, such as the pandemic, have intense effects on the markets. Knowing the course of fluctuations created by these crises in the economy and regulatory taking measures accordingly will be able to reduce the volume of fluctuations.

\section{References}

Atarodi, S., Dehghan, A., \& Asgari, M. (2018). The Effect of Exchange Rate Fluctuations and Oil Prices on the Export-Oriented Industries of the Country's Capital Market (Case Study: Stock Companies of Petrochemical Industry). International Journal of Economics and Financial Issues, 8(1), 136-42.

Ataş, H., \& Güler, H. (2020). Türkiye'nin Doğal Gaz, Petrol ve Kömür Tüketiminin Büyümeye Etkisi: Ekonometrik Bir Analiz (The Effects of Turkey's Natural Gas, Oil and Coal Consumption on Growth: An Econometric Analysis). Çukurova Üniversitesi Sosyal Bilimler Enstitüsü Dergisi, 29(3), 524-39.

Aydoğuş, O. (2020). Salgın ve Ekonomik Kriz (Pandemic and Economic Crisis). In İktisat ve Toplum Dergisi (Vol. 114). 
Bayraç, H. N. (2019). Küresel Petrol Piyasasında Fiyat Oluşumu ve Ekonomik Etkileri (Price Formation in the Global Petroleum Market and Its Economic Effects). Yalova Sosyal Bilimler Dergisi, 9(19), 44-59.

Brown, D. J., \& Schrader, L. F. (1990). Cholesterol Information and Shell Egg Consumption. American Journal of Agricultural Economics, 72 (3), 548-55. doi:10.2307/1243023

Caporale, G. M., Ali, F. M., \& Spagnolo, N. (2015). Oil Price Uncertainty and Sectoral Stock Returns in China: A Time-varying Approach. China Economic Review, 34, 311-21. doi:10.1016/j.chieco.2014.09.008

Central Bank of Republic of Turkey (CBRT). (2021). Electronic Data Distribution System. https://evds2.tcmb.gov.tr/.

Chern, W., \& Rickertsen, K. (2003). Health, Nutrition and Food Demand. Cabi Publishing, Wallingford.

Chern, W., \& Zuo, J. (2006). Impacts of Fat and Cholesterol Information on Consumer Demand: Application of News Indexes (Working Papers No. 28321). The Ohio State University.

Çolak, Ö. F. (2020). Salgına Karşı Ekonomik Önlemler Artırılmalı (Economic Measures Against the Pandemic Should be Increased). In Iktisat ve Toplum Dergisi (Vol. 114).

Constant, Z. S. (2010). Export-Led Growth Hypothesis: Evidence from Cote d'Ivoire (Working Papers). SSRN. doi:10.2139/ssrn.2501806

Dickey, D. A., \& Fuller, W. A. (1979). Distribution of the Estimators for Autoregressive Time Series with a Unit Root. Journal of American Statistical Association, $74(366)$, 427-31. doi: $10.2307 / 2286348$

Elmastaş Gültekin, Ö. and Aktürk Hayat, E. (2016). Altın Fiyatını Etkileyen Faktörlerin VAR Modeli İle Analizi: 2005-2015 Dönemi (Analysis of Factors Affecting the Gold Price Through VAR Model: 2005-2015 Period). Ege Academic Review, 16(4), 611-25.

Engle, R. F., \& Granger, C. W. J. (1987). Co-Integration and Error Correction: Representation, Estimation, and Testing. Econometrica, 55(2), 251-76. doi:10.2307/1913236

Ewing, B. T., Riggs, K., \& Ewing, K. L. (2007). Time Series Analysis of a Predator-prey System: Application of VAR and Generalized Impulse Response Function. Ecological Economics, 60(3), 605-12. doi:10.1016/j.ecolecon.2006.01.002

Gourène, G. A. Z., \& Mendy, P. (2018). Oil Prices and African Stock Markets Comovement: A Time and Frequency Analysis. Journal of African Trade, 5(1-2), 55-67. doi:10.1016/j.joat.2018.03.002

Greenwood, J., \& Smith, B. D. (1997). Financial Markets in Development, and the Development of Financial Markets. Journal of Economic Dynamics and Control, 21(1), 145-81. doi:10.1016/0165-1889(95)00928-0

Gönüllü, Ç. \& Otluoğlu, E. \& Şengöz, M. (2015). Ham Petrol Fiyatı Değişimlerinin Petrokimya Sektörü Getirileri Üzerindeki Etkisi (The Impact of Crude Oil Price Changes on Petrochemical Industry Returns). Uluslararası İktisadi ve İdari İncelemeler Dergisi, $7(14), 223-34$. 
Gürdamar, B. (2020). Uzmanlardan 'Yeni Borsa Mağdurları Olmasın' Uyarısı ('No New Stock Market Victims' Warning from Experts). https://www.aa.com.tr/tr/ekonomi/ uzmanlardan-yeni-borsa-magdurlari-olmasin-uyarisi/2090715.

Investing. (2021). BIST Chemical, Petroleum $\mathscr{E}$ Plastic (XKMYA). https://tr. investing .com/indices/ise-chem., petrol.,plastic.

Johansen, S. (1995). Likelihood Based Inference in Cointegrated Vector Autoregressive Models. Oxford University Press.

Kiss, G. D., Tanács, G. Z., Lippai-Makra, E., \& Rácz, T. A. (2020). Last Resort: European Central Bank's Permanent Engagement in Tackling Foreign Exchange Liquidity Disruptions in the Euro Area Banking System. Financial and Economic Review, 19(4), 83-106. doi:10.33893/FER.19.4.83106

Korcan, U. (2021). Temettü Verimi Yüksek Hisseden Çifte Kazanç (Double Earnings from High Dividend Yield). https://www.dunya.com/finans/haberler/borsa/ temettu-verimi-yuksek-hisseden-cifte-kazanc-haberi-610821.

Levine, R., \& Zervos, S. (1996). Stock Market Development and Long-run Growth. The World Bank Economic Review, 10(2), 323-39. doi:10.1093/wber/10.2.323

Liu, F., Shao, S., \& Zhang, C. (2020). How Do China's Petrochemical Markets React to Oil Price Jumps? A Comparative Analysis of Stocks and Commodities. Energy Economics, 92. doi: $10.1016 / \mathrm{j}$.eneco.2020.104979

Lütkepohl, H. (2015). Vector Autoregressive Models. In N. Hashimzade \& M. A. (Eds.), Handbook of Research Methods and Applications in Empirical Macroeconomics. Edward Elgar Publishing.

Lütkepohl, H., \& Kratzig, M. (2004). Applied Time Series Econometrics. Cambridge University Press. doi:10.1017/CBO9780511606885

Mensi, W. (2019). Global Financial Crisis and Co-movements between Oil Prices and Sector Stock Markets in Saudi Arabia: A VAR based Wavelet. Borsa Istanbul Review, 19(1), 24-38. doi:10.1016/j.bir.2017.11.005

Ministry of Health of Republic of Turkey (MoH). (2021). General Coronavirus Table - COVID-19 Information Page. https://covid19.saglik.gov.tr/TR-66935/genel -koronavirus-tablosu.html.

Özer, A. (2017). Petrol Fiyatları ile Hisse Senedi Getirileri Arasında Volatilitenin Yayılma Etkisi: Gelişmiş ve Gelişmekte olan Ülkeler Örneği (Volatility Spillovers between Oil Prices and Stock Returns: Developed and Developing Countries Case). International Journal of Management Economics $\& 3$ Business/Uluslararası Yönetim Iktisat ve Işletme Dergisi, 13(13), 654-62.

Öztürk, M. B. \& Gümüs, G. K. \& Taşkın, F. D. \& Çağlı, E. Ç. (2013). Petrol ve Doğalgaz Fiyatları ile İmalat ve Kimya-petrol-plastik Sektörlerinin Endeksleri Arasındaki İlişki (The Relationship between Oil and Natural Gas Prices and Manufacturing and ChemicalPetroleum-Plastic Industry). Niğde Üniversitesi İktisadi ve İdari Bilimler Fakültesi Dergisi, 6(2), 64-74.

Oğuz, A. (2018). Özelleştirmenin Gerekçesi ve Etkinliği: Petro-Kimya Firmaları Üzerine Bir Uygulama (Rationale and Effectiveness of Privatization: An Application on PetroChemical Companies). In A. Oğuz (Ed.), Türkiye'de Ekonomi-Yönetim-Siyaset Üzerine (On Economy-Management-Politics in Turkey). Academia Publishing. 
Phillips, P., \& Perron, P. (1988). Testing for a Unit Root in Time Series Regression. Biometrika, 75(2), 335-46. doi:10.2307/2336182

Rafiq, S., Salim, R., \& Bloch, H. (2009). Impact of Crude Oil Price Volatility on Economic Activities: An Empirical Investigation in the Thai Economy. Resources Policy, 34(3), 121-32. doi:10.1016/j.resourpol.2008.09.001

Sims, C. A. (1980). Macroeconomics and Reality. Econometrica, 48(1), 1-48. doi: $10.2307 / 1912017$

Stock, J. H., \& Watson, M. W. (2001). Vector Autoregressions. Journal of Economic perspectives, 15(4), 101-15. doi:10.1257/jep.15.4.101

Turkish Plastics Industrialists Research, Development and Education Foundation (PAGEV). (2021). Petrokimya Endüstrisi ile Illgili Sorular, Cevaplar (Questions and Answers Related to the Petrochemical Industry). https://pagev.org/petrokimya-endustrisi-ile -ilgili-sorular-cevaplar.

Turkish Statistical Institute (TURKSTAT). (2021). Producer Price Index. https:// tuikweb.tuik.gov.tr.

Verbeek, T., \& Mah, A. (2020). Integration and Isolation in the Global Petrochemical Industry: A Multiscalar Corporate Network Analysis. Economic Geography, 96(4), 36387. doi:10.1080/00130095.2020.1794809

Weinhagen, J. (2002). An Empirical Analysis of Price Transmission by Stage of Processing. Monthly Labor Review, 125(11), 3-11. doi:10.1023/A:1011043120145 


\section{Appendix: Additional Tables}

Table A.1: Results of Variance Decomposition for VAR model

\begin{tabular}{|c|c|c|c|c|c|}
\hline \multirow[b]{2}{*}{ Period } & \multirow[b]{2}{*}{ S.E. } & \multicolumn{4}{|c|}{ Variance Decomposition of Lreelbistpetrochemical } \\
\hline & & Lreelbistpetro & Doilprice & Dexchangerate & Lpandemicindex \\
\hline 1 & 0.0361 & 100.0000 & 0.0000 & 0.0000 & 0.0000 \\
\hline 2 & 0.0493 & 99.1908 & 0.2584 & 0.2302 & 0.3206 \\
\hline 3 & 0.0575 & 98.5065 & 0.5122 & 0.3041 & 0.6772 \\
\hline 4 & 0.0643 & 97.5661 & 1.1084 & 0.3596 & 0.9659 \\
\hline 5 & 0.0702 & 96.6818 & 1.6983 & 0.4461 & 1.1738 \\
\hline 6 & 0.0754 & 95.8693 & 2.2356 & 0.5185 & 1.3766 \\
\hline 7 & 0.0799 & 95.0031 & 2.7988 & 0.5541 & 1.6439 \\
\hline 8 & 0.0841 & 93.9731 & 3.4475 & 0.5728 & 2.0066 \\
\hline 9 & 0.0879 & 92.7548 & 4.2000 & 0.5879 & 2.4573 \\
\hline 10 & 0.0916 & 91.3629 & 5.0573 & 0.6017 & 2.9781 \\
\hline 11 & 0.0950 & 89.8131 & 6.0148 & 0.6136 & 3.5586 \\
\hline 12 & 0.0983 & 88.1113 & 7.0681 & 0.6233 & 4.1973 \\
\hline \multirow[b]{2}{*}{ Period } & \multicolumn{5}{|c|}{ Variance Decomposition of Doilprice: } \\
\hline & S.E. & Lreelbistpetro & Doilprice & Dexchangerate & Lpandemicindex \\
\hline 1 & 0.0535 & 5.4239 & 94.5761 & 0.0000 & 0.0000 \\
\hline 2 & 0.0571 & 9.2699 & 83.2126 & 0.4050 & 7.1124 \\
\hline 3 & 0.0595 & 8.7104 & 79.6889 & 0.3728 & 11.2279 \\
\hline 4 & 0.0604 & 8.6097 & 78.8751 & 1.2572 & 11.2580 \\
\hline 5 & 0.0606 & 8.5699 & 78.5019 & 1.5795 & 11.3486 \\
\hline 6 & 0.0607 & 8.6123 & 78.2731 & 1.5799 & 11.5348 \\
\hline 7 & 0.0608 & 8.7004 & 78.1745 & 1.5886 & 11.5365 \\
\hline 8 & 0.0608 & 8.7463 & 78.1030 & 1.5972 & 11.5535 \\
\hline 9 & 0.0608 & 8.7683 & 78.0174 & 1.5992 & 11.6151 \\
\hline 10 & 0.0609 & 8.7907 & 77.9497 & 1.5974 & 11.6621 \\
\hline 11 & 0.0609 & 8.8173 & 77.9056 & 1.5955 & 11.6816 \\
\hline 12 & 0.0609 & 8.8449 & 77.8722 & 1.5941 & 11.6887 \\
\hline \multirow{2}{*}{\multicolumn{6}{|c|}{ Variance Decomposition }} \\
\hline & S.E. & Lreelbistpetro & Doilprice & Dexchangerate & Lpandemicindex \\
\hline 1 & 0.0142 & 12.5719 & 0.0049 & 87.4233 & 0.0000 \\
\hline 2 & 0.0163 & 22.0282 & 0.5318 & 77.3615 & 0.0785 \\
\hline 3 & 0.0164 & 21.9036 & 0.5751 & 77.3689 & 0.1525 \\
\hline 4 & 0.0166 & 22.8834 & 0.6104 & 76.1693 & 0.3369 \\
\hline 5 & 0.0166 & 22.9141 & 0.6667 & 76.0658 & 0.3534 \\
\hline 6 & 0.0166 & 22.8928 & 0.6660 & 76.0702 & 0.3709 \\
\hline 7 & 0.0166 & 22.9342 & 0.6790 & 75.9892 & 0.3976 \\
\hline 8 & 0.0166 & 23.0163 & 0.6898 & 75.8882 & 0.4057 \\
\hline 9 & 0.0166 & 23.0719 & 0.6968 & 75.8239 & 0.4075 \\
\hline 10 & 0.0166 & 23.1108 & 0.7035 & 75.7769 & 0.4089 \\
\hline 11 & 0.0166 & 23.1489 & 0.7107 & 75.7287 & 0.4116 \\
\hline 12 & 0.0166 & 23.1865 & 0.7191 & 75.6779 & 0.4165 \\
\hline \multicolumn{6}{|c|}{ Varia } \\
\hline Period & S.E. & Lreelbistpetro & Doilprice & Dexchangerate & Lpandemicindex \\
\hline 1 & 0.1075 & 2.1851 & 39.3875 & 0.0000 & 58.4274 \\
\hline 2 & 0.2165 & 3.6574 & 44.8657 & 0.0342 & 51.4428 \\
\hline 3 & 0.2956 & 4.8404 & 47.1472 & 0.0469 & 47.9655 \\
\hline 4 & 0.3551 & 5.6343 & 49.6268 & 0.0583 & 44.6805 \\
\hline 5 & 0.4031 & 6.1201 & 51.5673 & 0.0691 & 42.2435 \\
\hline 6 & 0.4458 & 6.4011 & 52.7884 & 0.0722 & 40.7384 \\
\hline 7 & 0.4868 & 6.5050 & 53.4849 & 0.0660 & 39.9441 \\
\hline 8 & 0.5279 & 6.4765 & 53.9158 & 0.0580 & 39.5498 \\
\hline 9 & 0.5695 & 6.3623 & 54.2679 & 0.0517 & 39.3182 \\
\hline 10 & 0.6111 & 6.2023 & 54.6192 & 0.0480 & 39.1305 \\
\hline 11 & 0.6527 & 6.0236 & 54.9721 & 0.0463 & 38.9580 \\
\hline 12 & 0.6943 & 5.8383 & 55.3070 & 0.0456 & 38.8091 \\
\hline
\end{tabular}


Table A.2: Lag length selection in VAR model

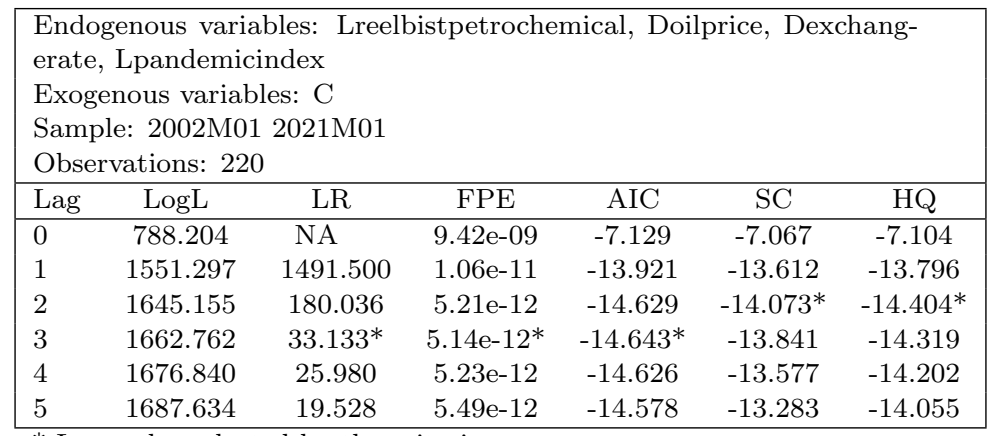

* Lag order selected by the criterion.

LR: Sequential modified LR test statistic (each test at $5 \%$ level)

FPE: Final Prediction Error

AIC: Akaike Information Criterion

SC: Schwarz Information Criterion

HQ: Hannan-Quinn information criterion

Table A.3: VAR Granger Causality/Block Exogeneity Wald Tests

\begin{tabular}{|c|c|c|c|}
\hline Excluded & Chi-sq & $\mathrm{df}$ & Prob. \\
\hline \multicolumn{4}{|c|}{ Dependent variable: Lbistpetrochemical } \\
\hline Doilprice & 0.531 & 3 & 0.912 \\
\hline Dexchangerate & 0.985 & 3 & 0.805 \\
\hline lpandemindex & 6.216 & 3 & 0.102 \\
\hline All & 7.867 & 9 & 0.548 \\
\hline \multicolumn{4}{|c|}{ Dependent variable: Doilprice } \\
\hline Lbistpetrochemical & 14.638 & 3 & 0.002 \\
\hline Dexchangerate & 4.290 & 3 & 0.232 \\
\hline lpandemindex & 31.897 & 3 & 0.000 \\
\hline All & 50.376 & 9 & 0.000 \\
\hline \multicolumn{4}{|c|}{ Dependent variable: Dexchangerate } \\
\hline Lbistpetrochemical & 17.735 & 3 & 0.001 \\
\hline Doilprice & 0.581 & 3 & 0.901 \\
\hline lpandemindex & 0.373 & 3 & 0.946 \\
\hline All & 22.239 & 9 & 0.008 \\
\hline \multicolumn{4}{|c|}{ Dependent variable: lpandemindex } \\
\hline Lbistpetrochemical & 2.150 & 3 & 0.542 \\
\hline Doilprice & 9.535 & 3 & 0.023 \\
\hline Dexchangerate & 0.495 & 3 & 0.920 \\
\hline All & 13.617 & 9 & 0.137 \\
\hline
\end{tabular}

